\title{
Halomonas boliviensis sp. nov., an alkalitolerant, moderate halophile isolated from soil around a Bolivian hypersaline lake
}

\author{
Jorge Quillaguamán, ${ }^{1,2}$ Rajni Hatti-Kaul, ${ }^{1}$ Bo Mattiasson, ${ }^{1}$ \\ Maria Teresa Alvarez ${ }^{1,3}$ and Osvaldo Delgado ${ }^{1} \dagger$ \\ ${ }^{1}$ Department of Biotechnology, Centre for Chemistry and Chemical Engineering, Lund \\ University, PO Box 124, SE-22100 Lund, Sweden \\ ${ }^{2}$ Centro de Biotecnología, Facultad de Ciencias y Tecnología, Universidad Mayor de San \\ Simón, Cochabamba, Bolivia \\ ${ }^{3}$ Instituto de Investigaciones Farmaco Bioquímicas, Universidad Mayor de San Andrés, La Paz, \\ Bolivia
}

Correspondence

Jorge Quillaguamán

Jorge.Quillaguaman@biotek.lu.se

\begin{abstract}
Halomonas boliviensis sp. nov. is proposed for two moderately halophilic, psychrophilic, alkalitolerant bacteria, $\mathrm{LC}^{\top}{ }^{\top}\left(=\mathrm{DSM} 15516^{\top}=\mathrm{ATCC}^{\left.\mathrm{BAA}-759^{\top}\right)}\right.$ ) and LC2 $(=\mathrm{DSM}$ $15517=$ ATCC BAA-760), both of which were isolated from a soil sample around the lake Laguna Colorada, located at $4300 \mathrm{~m}$ above sea level in the south-west region of Bolivia. The bacteria are aerobic, motile, Gram-negative rods that produce colonies with a cream pigment. Moreover, they are heterotrophs that are able to utilize various carbohydrates as carbon sources. The organisms reduce nitrate and show tryptophan deaminase activity. The genomic DNA G $+\mathrm{C}$ contents were $51.4 \mathrm{~mol} \%$ for isolate $\mathrm{LC}^{\top}$ and $52.6 \mathrm{~mol} \%$ for isolate LC2. Based on $16 \mathrm{~S}$ rDNA sequence analysis, isolates $L C 1^{\top}$ and $L C 2$ were identified as members of the genus Halomonas and clustered closely with Halomonas variabilis DSM $3051^{\top}$ and Halomonas meridiana DSM $5425^{\top}$. However, DNA-DNA relatedness between the new isolates and the closest related Halomonas species was low.
\end{abstract}

During the last decade, extensive studies of hypersaline environments in different geographical locations have led to the isolation and characterization of a large number of moderately halophilic species (Ventosa et al., 1998; Oren, 2002).

Many Gram-negative, halotolerant or halophilic species are currently included in the family Halomonadaceae, which belongs to the $\gamma$-subclass of the Proteobacteria. Among the genera that comprise this family, Halomonas covers the major number of species $(>20)$ with heterogeneous features and has recently been distinguished into two phylogenetic groups, based on $16 \mathrm{~S}$ and $23 \mathrm{~S}$ rDNA sequences

Published online ahead of print on 21 November 2003 as DOI 10.1099/ijs.0.02800-0.

tPresent address: PROIMI-CONICET, Av. Belgrano y Pasaje, Caseros, 4000 Tucumán, Argentina.

The GenBank/EMBL/DDBJ accession numbers for the 16S rDNA sequences of isolates LC1 ${ }^{\top}$ and LC2 are AY245449 and AY245450, respectively.

A table showing differential characteristics of $H$. boliviensis from other Halomonas species and micrographs of $H$. boliviensis strains are available as supplementary material in IJSEM Online. of the different species (Arahal et al., 2002). It has also been noted that the genus Halomonas has an unusually wide range of DNA G + C content, of about 52-68 mol\% (Arahal et al., 2002). We have isolated a number of moderately halophilic organisms from the south-west region of Bolivia, which lies between the eastern and western ranges of the South American Andes. Much of this region lies $>4000 \mathrm{~m}$ above sea level, allowing the survival of limited and unique flora and fauna. A number of lakes that have been formed because of evaporation exceeding rainfall and the presence of undrained, intravolcanic basins (Risacher, 1992) contain salt concentrations in the range of $10-103 \mathrm{~g} \mathrm{l}^{-1}$ (Hurlbert \& Chang, 1988).

This study describes the characterization and identification of two strains, $\mathrm{LCl}^{\mathrm{T}}$ and $\mathrm{LC} 2$, that belong to the genus Halomonas and were isolated from a soil sample around Laguna Colorada (red-coloured lake), a large, shallow, hypersaline lagoon that is located $4300 \mathrm{~m}$ above sea level $\left(22^{\circ} 13^{\prime} 7^{\prime \prime} \mathrm{S} 67^{\circ} 48^{\prime} 28^{\prime \prime} \mathrm{E}\right)$ (Jones, 1993). The name of the lake is attributed to the red colour provided by algal communities and halophilic micro-organisms that are present in the waters. The area is of volcanic origin and the lagoon is partly fed by geothermal springs. Other sources of 
water include the inflow of two rivers, Río Sulor and Río Aguaditas. The lagoon is surrounded by thin, sandy, volcanic soils with high concentrations of sodium, potassium, magnesium, boron, arsenic, lead, borax, gypsum, sulphates and phosphates (Jones, 1993). The environmental temperature varies between -15 and $20^{\circ} \mathrm{C}$ during the year.

The medium used for isolation and maintenance of the bacteria was that descried by Ventosa et al. (1982). The medium contained (\%, w/v): $\mathrm{NaCl}, 17 \cdot 8 ; \mathrm{MgSO}_{4} .7 \mathrm{H}_{2} \mathrm{O}, 0 \cdot 1$; $\mathrm{CaCl}_{2} .2 \mathrm{H}_{2} \mathrm{O}, 0 \cdot 036 ; \mathrm{KCl}, 0 \cdot 2 ; \mathrm{NaHCO}_{3}, 0 \cdot 006 ; \mathrm{NaBr}, 0 \cdot 023$; proteose/peptone (Difco), 0.5; yeast extract (Difco), $1 \cdot 0$; glucose, $0 \cdot 1$; and (for solid medium) granulated agar, $2 \cdot 0$. The $\mathrm{pH}$ was adjusted to $7 \cdot 5$ by using $3 \mathrm{M} \mathrm{NaOH}$, to make it similar to that of the soil sample. The isolation procedure consisted of mixing about $500 \mathrm{mg}$ soil sample from the shore of Laguna Colorada, Bolivia, with $0.5 \mathrm{ml}$ medium by gentle vortexing, inoculating $0 \cdot 2 \mathrm{ml}$ mixture into a $250 \mathrm{ml}$ Erlenmeyer flask that contained $100 \mathrm{ml}$ medium and incubating for 12 days at $15^{\circ} \mathrm{C}$ with shaking at 200 r.p.m. The enriched bacterial medium was diluted by using sterile liquid medium and then surface-inoculated onto solid agar medium for 10 days further incubation at $18^{\circ} \mathrm{C}$. Colonies were isolated, taking their morphological differences into consideration.

The medium (HM) for bacterial growth and characterization was based on the isolation medium and had the following composition $(\%, \mathrm{w} / \mathrm{v}): \mathrm{NaCl}, 4 \cdot 45 ; \mathrm{MgSO}_{4} \cdot 7 \mathrm{H}_{2} \mathrm{O}$, $0.025 ; \mathrm{CaCl}_{2} .2 \mathrm{H}_{2} \mathrm{O}, 0 \cdot 009 ; \mathrm{KCl}, 0 \cdot 05 ; \mathrm{NaBr}, 0 \cdot 006$; proteose/ peptone (Difco), $0 \cdot 5$; yeast extract (Difco), $1 \cdot 0$; glucose, $0 \cdot 1$; and (for solid medium) granulated agar, $2 \cdot 0 \%$; the $\mathrm{pH}$ was adjusted to $7 \cdot 5$ by using $1 \mathrm{M} \mathrm{KOH}$.

Cells of strains $\mathrm{LC}^{\mathrm{T}}$ and LC2 were grown in HM medium at $25^{\circ} \mathrm{C}$ and $\mathrm{pH} 7 \cdot 5$ unless otherwise stated. Cell size and morphology were examined from $20 \mathrm{~h}$ bacterial cultures by using a Nikon Optiphot- 2 phase-contrast microscope at magnification $\times 1000$. Gram staining was performed by using a Difco Gram stain set.

Colony morphology was analysed after growth for $30 \mathrm{~h}$ at $30^{\circ} \mathrm{C}$ on solid medium, according to Smibert \& Krieg (1994). Bacterial flagella were observed by using a JEM-123 (HC) transmission electron microscope after staining with $2 \%$ uranyl acetate, according to Vreeland et al. (1980). Cells were also observed under a JSM-5600 LV scanning electron microscope (JEOL). For this, cells were harvested from liquid cultures during their exponential-growth phase, washed twice with water and dehydrated through a graded series of ethanol and isopropyl alcohol/aqueous solutions. Cells were then mounted on $12 \mathrm{~mm}$ cover slips, dried overnight in a vacuum desiccator and then coated with gold/ palladium $(80: 20)$.

Sugar assimilation was determined by using the API 50 CHB system (bioMérieux). Other biochemical characteristics were screened by the API 20E system, according to Logan \& Berkeley (1984).
Growth at and tolerance to salt concentration, temperature and $\mathrm{pH}$ of isolates $\mathrm{LC1}^{\mathrm{T}}$ and $\mathrm{LC} 2$ were studied in $12 \mathrm{ml} \mathrm{HM}$ medium in $50 \mathrm{ml}$ screw-capped bottles. For these studies, cells were respectively grown at $0,5,10,15,25$ and $30 \%$ $(\mathrm{w} / \mathrm{v}) \mathrm{NaCl}$ for 10 days; at temperatures of $0,4,15,25,35$, 45 and $50^{\circ} \mathrm{C}$ for 14 days; and at initial $\mathrm{pH}$ values of 4,5 , $6,7,8,9,10$ and 11 (adjusted with $2 \mathrm{M} \mathrm{KOH}$ or $2 \mathrm{M} \mathrm{HCl}$ ) for 10 days. $\mathrm{OD}_{600}$ was measured in an Ultrospec 3000 spectrophotometer (Pharmacia Biotech) by using sterile medium as the reference. Slopes of $\mathrm{OD}_{600}$ versus salt concentration, temperature and $\mathrm{pH}$ were plotted for determination of optimal conditions for growth.

Sensitivity to antibiotics was determined by the standard disc assay method, according to Smibert \& Krieg (1994). Resistance and degree of sensitivity were determined by measuring the size of inhibition zones from different amounts of each antibiotic after $24 \mathrm{~h}$ incubation at $30^{\circ} \mathrm{C}$.

Genomic DNA was extracted and purified according to Marmur (1961) and its purity was assessed from $A_{260} / A_{280}$ and $A_{260} / A_{230}$ ratios (Johnson, 1994). Universal primers that corresponded to positions 8-27F (5'-AGAGTTTGATCCTGGCTCAG-3') and 1422R (5'-GGTTACCTTGTTACGACTT-3') were used to amplify the $16 \mathrm{~S}$ rDNA region of isolates $\mathrm{LC}^{\mathrm{T}}$ and LC2 (Weisburg et al., 1991). PCR products were purified by using a QIAquick PCR Purification kit (Qiagen) and were then resuspended in $40 \mu \mathrm{l}$ sterile water. DNA sequencing of both strands was performed by the dideoxy chain-termination method with an ABI Prism 3100 DNA analyser, using an ABI Prism BigDye Terminator Cycle Sequencing Ready Reaction kit (PE Biosystems) according to the protocol supplied by the manufacturer. GenBank and the RDP database were used to search for 16S rDNA sequence similarities (Maidak et al., 2000). Phylogenetic analysis of $16 \mathrm{~S}$ rDNA sequences was performed with the aid of the MEGA2 software package (Kumar et al., 2001) by using the neighbour-joining method (Saitou \& Nei, 1987). For phylogenetic trees, only sequences from the type strains of species whose names have been validly published were taken into account. Almost-complete $16 \mathrm{~S}$ rDNA sequences (about $1460 \mathrm{bp}$ ) of isolates $\mathrm{LC}^{\mathrm{T}}{ }^{\mathrm{T}}$ and LC2 were used in the analysis.

Genomic DNA $\mathrm{G}+\mathrm{C}$ content was determined and DNA-DNA hybridization was performed by Deutsche Sammlung von Mikroorganismen und Zellkulturen (DSMZ, Braunschweig, Germany). For these assays, isolates $\mathrm{LC}^{\mathrm{T}}$ and LC2 were grown in HM medium and reference strains Halomonas variabilis DSM $3051^{\mathrm{T}}$ and Halomonas meridiana DSM $5425^{\mathrm{T}}$ were grown according to the conditions given by DSMZ.

Among the strains isolated from the Laguna Colorada soil sample, two isolates, namely $\mathrm{LC}^{\mathrm{T}}$ and LC2, were placed within the genus Halomonas by their $16 \mathrm{~S}$ rDNA sequence (Fig. 1). 16S rDNA sequence similarity between $\mathrm{LC1}^{\mathrm{T}}$ and LC2 was $99 \cdot 7 \%$. They were placed in a parallel branch with $H$. variabilis DSM $3051^{\mathrm{T}}$ (with $98 \cdot 7 \%$ similarity) and 


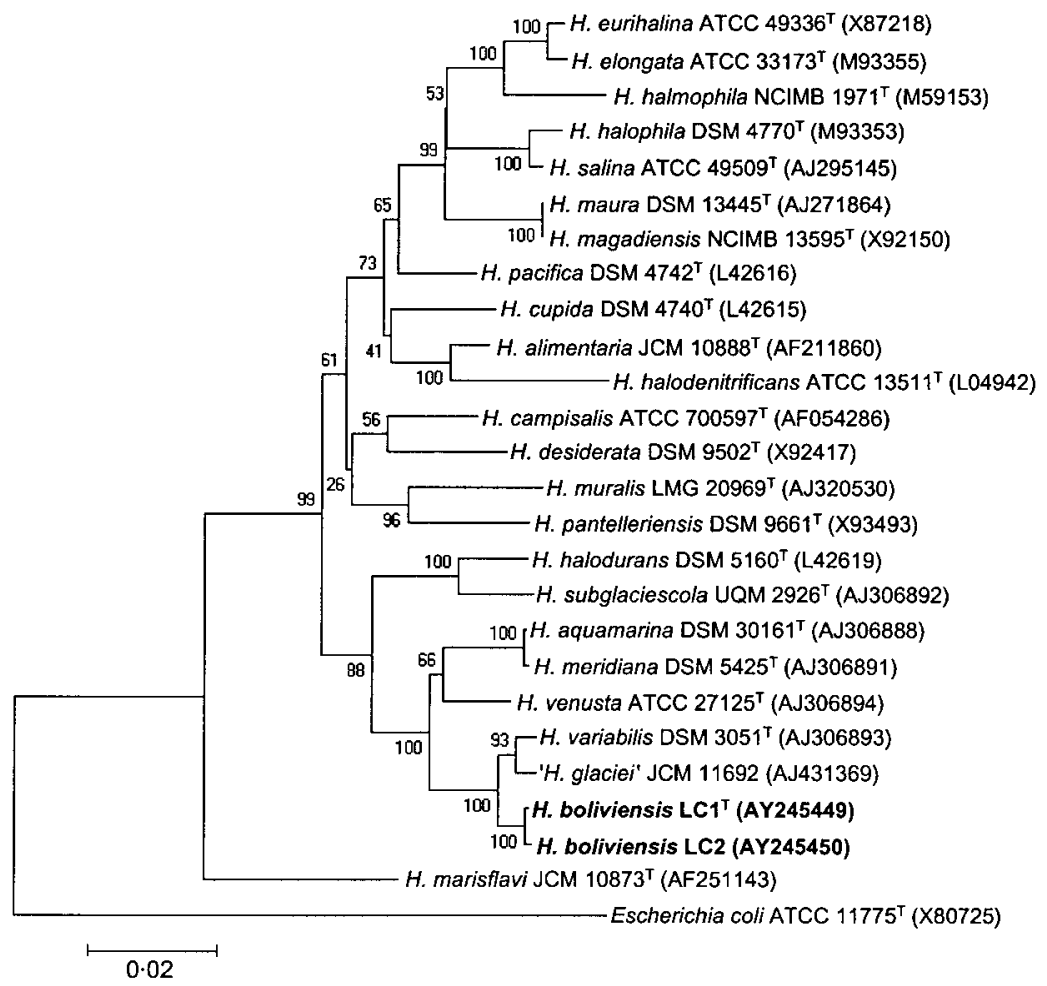

Fig. 1. Phylogenetic tree constructed from comparison of the $16 \mathrm{~S}$ rDNA sequences of isolates $\mathrm{LC}_{1}{ }^{\top}$ and LC2 with those of members of the genus Halomonas. GenBank accession numbers of the type strains used in the phylogenetic analysis are given in parentheses. Escherichia coli was taken as the outgroup. Bar, 2 substitutions in 100 nt. with $H$. meridiana DSM $5425^{\mathrm{T}}$, with which they displayed $97 \%$ similarity.

Several morphological and taxonomic features of isolates $\mathrm{LCl}^{\mathrm{T}}$ and LC2 were investigated and compared with those of $H$. variabilis and $H$. meridiana (see Supplementary Table, available in IJSEM Online). In this comparison, 'Halomonas glaciei MTCC 4321, a novel species that was reported recently (Reddy et al., 2003), was also added. Furthermore, type strains of the genus Halomonas that belong to other clusters were also included.

In previous studies, Tindall (1994) and Baumgarte et al. (2001) showed that biochemical and chemical data sometimes contradicted the conclusion derived from $16 \mathrm{~S}$ rDNA sequences of the organisms. In the present work, the Supplementary Table (available in IJSEM Online) shows several taxonomic and physiological differences of isolates $\mathrm{LC1}^{\mathrm{T}}$ and LC2 from the closest related species, $H$. variabilis. Indeed, there are more differences than similarities, although the new isolates shared some characteristics with $H$. meridiana, such as their wide range of salt tolerance and growth temperature.

Isolates $\mathrm{LC}^{\mathrm{T}}$ and LC2 were motile by means of lophotrichous flagella (Supplementary Fig. A, available in IJSEM Online) and were Gram-negative, rod-shaped organisms that were found both singly and in pairs [Supplementary Figs B and C (left), available in IJSEM Online] and occasionally as cellular chains of three bacteria during their exponential phase. Cells exhibited varying lengths during the exponential phase [Figs B and C (right), available in IJSEM Online]; however, they became shorter and more uniformly long when reaching the end of their exponential phase. Furthermore, both isolates showed binary fission in short cells [Supplementary Fig. C (left), available in IJSEM Online), whereas apical and transverse fission was observed in elongated cells, as a result of cell division (Supplementary Fig. B, available in IJSEM Online). Two principal differences were seen in the cellular morphology of the two isolates: cells of strain LC2 were longer than those of $\mathrm{LCl}^{\mathrm{T}}$ (see Supplementary Table in IJSEM Online) and their shape became slightly curved in short rods, whereas isolate $\mathrm{LC1}^{\mathrm{T}}$ maintained a straight rod shape during its exponential-growth phase.

Both isolates showed similar tolerance and optimal growth conditions with respect to $\mathrm{pH}$, temperature and salinity. The organisms grew optimally at an $\mathrm{NaCl}$ concentration of $5 \%$ $(\mathrm{w} / \mathrm{v})$ and tolerated up to $25 \%(\mathrm{w} / \mathrm{v}) \mathrm{NaCl}$, hence they can be considered as moderately halophilic bacteria (Ventosa et al., 1998). These characteristics were in contrast to those of $H$. variabilis and $H$. meridiana (see Supplementary Table in IJSEM Online). Nevertheless, salt requirement and tolerance may vary according to growth temperature and nature of nutrients available (Ventosa et al., 1998). Optimum temperature for growth was about $25-30{ }^{\circ} \mathrm{C}$; the isolates were able to grow at $0{ }^{\circ} \mathrm{C}$ (the lowest temperature tested) and up to $45^{\circ} \mathrm{C}$ and could be classified as psychrophiles [according to the definition of Morita (1975)], whereas H. variabilis is a mesophilic bacterium 
that can only grow at $15-37^{\circ} \mathrm{C}$ (Fendrich, 1988). Finally, cells were able to grow in a broad $\mathrm{pH}$ range of 6-11 with an optimal $\mathrm{pH}$ for growth between $7 \cdot 5$ and 8 , and can therefore be considered to be alkalitolerant (like other Halomonas species), although with varying $\mathrm{pH}$ limits for growth (see Supplementary Table in IJSEM Online).

Strains $\mathrm{LC1}^{\mathrm{T}}$ and LC2 utilized a variety of carbohydrates as carbon sources, the latter organism exhibiting wider versatility in choice of substrate. The heterotrophic behaviour and ability of the isolates to utilize different kinds of carbohydrates was similar to that of $H$. meridiana, but differed from $H$. variabilis, which is known for being chemo-organotrophic and for its inability to oxidize carbohydrates (Fendrich, 1988). Even 'H. glaciei' strains have shown a rather restricted ability for utilization of different carbon sources (Reddy et al., 2003).

Isolates $\mathrm{LC}^{\mathrm{T}}$ and LC2 were comparable with respect to their biochemical characteristics. Some of these characteristics were shared with reference Halomonas species, but differences were also noted (see Supplementary Table in IJSEM Online). The attribute that differentiated isolates $\mathrm{LC1}^{\mathrm{T}}$ and LC2 from $H$. meridiana, $H$. variabilis and ' $H$. glaciei' was their ability to reduce nitrate (see Supplementary Table in IJSEM Online). Furthermore, the presence of urease, which was observed in $H$. meridiana and H. variabilis, was not found in cells of strain $\mathrm{LCl}^{\mathrm{T}}$ or strain LC2. Many members of the genus Halomonas can use nitrate as an alternative electron acceptor (Ventosa et al., 1998). Some type strains that are able to reduce nitrate are included in the Supplementary Table (available in IJSEM Online); they did not, however, bear other significant phenotypic resemblance to isolates $\mathrm{LC1}^{\mathrm{T}}$ and LC2.

The DNA G $+\mathrm{C}$ contents of isolates $\mathrm{LC}^{\mathrm{T}}$ and LC2 $(51 \cdot 4$ and $52.6 \mathrm{~mol} \%$, respectively) differed significantly from those of $H$. variabilis, $H$. meridiana and ' $H$. glaciei', which have DNA G+C contents of 61,59 and $57 \mathrm{~mol} \%$, respectively. DNA-DNA relatedness between isolates $\mathrm{LCl}^{\mathrm{T}}$ and LC2 was $80 \cdot 4 \%$. DNA-DNA hybridization of the isolates with $H$. variabilis and $H$. meridiana gave $25 \cdot 4$ and $22 \cdot 8 \%$ similarity respectively for isolate $\mathrm{LCl}^{\mathrm{T}}$ and $29 \cdot 7$ and $21 \cdot 4 \%$ similarity respectively for isolate LC2. DNA-DNA similarities between the new isolates and reference bacteria were significantly lower than the recommended value of $\geqslant 70 \%$, which is accepted as the definition of a novel species (Wayne et al., 1987).

Based on DNA-DNA relatedness shared between isolates $\mathrm{LC}^{\mathrm{T}}$ and LC2, it can be concluded that these are different strains that belong to the same species. Moreover, because of low DNA-DNA hybridization similarities, marked difference in DNA G+C content from the Halomonas species with the highest $16 \mathrm{~S}$ rDNA sequence similarity and the new characteristics shown, we conclude that isolates $\mathrm{LC}^{\mathrm{T}}$ and LC2 constitute a novel species of the genus Halomonas, for which the name Halomonas boliviensis sp. nov. is proposed.

\section{Description of Halomonas boliviensis sp. nov.}

Halomonas boliviensis (bo.li.vi.en'sis. N.L. adj. boliviensis from Bolivia, relating to the country where the bacteria were isolated).

Aerobic, Gram-negative rods with a size of $0.4 \times 1 \cdot 1$ $0.6 \times 3 \cdot 4 \mu \mathrm{m}$ for isolate $\mathrm{LC}^{\mathrm{T}}$ and $0.4 \times 1 \cdot 1-0.5 \times 5 \cdot 5 \mu \mathrm{m}$ for isolate LC2. Motile by means of lophotrichous flagella. Cells occur singly or in pairs and show a wide size distribution during the exponential phase, but uniform size at the end of their growth. Colonies are circular with undulate margins, convex and have cream pigmentation that is enhanced in old cultures. Moderately halophilic, alkalitolerant and psychrophilic. Growth occurs at $0-25 \%$ $(\mathrm{w} / \mathrm{v}) \mathrm{NaCl}$ in complex medium, with an optimum of about $5 \%(\mathrm{w} / \mathrm{v}) \mathrm{NaCl}$. Growth occurs at $\mathrm{pH} 6-11$, with an optimum between $7 \cdot 5$ and 8 . Growth occurs at $0-45^{\circ} \mathrm{C}$, with an optimum between 25 and $30^{\circ} \mathrm{C}$. Heterotrophic cells that are able to utilize various carbohydrates as carbon sources. Nitrate reduction- and tryptophan deaminase-positive. No production of indole or sulphide occurs. Arginine dihydrolase-, $\beta$-galactosidase-, lysine decarboxylase-, ornithine decarboxylase- and VogesProskauer-negative. Gelatin is not liquefied. DNA G $+\mathrm{C}$ content is $51 \cdot 4 \mathrm{~mol} \%$ for strain $\mathrm{LCl}^{\mathrm{T}}$ and $52.6 \mathrm{~mol} \%$ for strain LC2. Both isolates are sensitive to erythromycin, tetracycline, kanamycin and carbenicillin; isolate $\mathrm{LCl}^{\mathrm{T}}$ is also sensitive to chloramphenicol and nalidixic acid.

The type strain is $\mathrm{LCl}^{\mathrm{T}}$ (=DSM $15516^{\mathrm{T}}=\mathrm{ATCC}$ BAA$\left.759^{\mathrm{T}}\right)$. Reference strain is LC2 $(=$ DSM $15517=$ ATCC BAA-760).

\section{Acknowledgements}

We would like to thank the Swedish International Development Cooperation Agency (Sida) for supporting this work. R. H.-K., B. M. and M. T. A. also thank Julio Cesar for being an invaluable guide for us during our scientific expedition with his incredible knowledge of the Bolivian landscape.

\section{References}

Arahal, D. R., Ludwig, W., Schleifer, K. H. \& Ventosa, A. (2002). Phylogeny of the family Halomonadaceae based on $23 \mathrm{~S}$ and $16 \mathrm{~S}$ rDNA sequence analyses. Int J Syst Evol Microbiol 52, 241-249.

Baumgarte, S., Moore, E. R. B. \& Tindall, B. J. (2001). Re-examining the $16 \mathrm{~S}$ rDNA sequence of Halomonas salina. Int J Syst Evol Microbiol 51, 51-53.

Fendrich, C. (1988). Halovibrio variabilis gen. nov. sp. nov, Pseudomonas halophila sp. nov. and a new halophilic aerobic coccoid Eubacterium from Great Salt Lake, Utah, USA. Syst Appl Microbiol 11, 36-43.

Hurlbert, S. H. \& Chang, C. C. Y. (1988). The distribution, structure, and composition of freshwater ice deposits in Bolivian salt lakes. Hydrobiologia 158, 271-299.

Johnson, J. L. (1994). Similarity analysis of DNAs. In Methods for General and Molecular Bacteriology, pp. 655-682. Edited by 
P. Gerhardt, R. G. E. Murray, W. A. Wood \& N. R. Krieg. Washington, DC: American Society for Microbiology.

Jones, T. A. (editor) (1993). A Directory of Wetlands of International Importance, 4th edn, vol. 4. Gland, Switzerland: Ramsar Convention Bureau.

Kumar, S., Tamura, K., Jakobsen, I. B. \& Nei, M. (2001). MEGA2: molecular evolutionary genetic analysis software. Bioinformatics 17, $1244-1245$.

Logan, N. A. \& Berkeley, C. W. (1984). Identification of Bacillus strains using the API system. J Gen Microbiol 130, 1871-1882.

Maidak, B. L., Cole, J. R., Lilburn, T. G. \& 9 other authors (2000). The RDP (Ribosomal Database Project) continues. Nucleic Acids Res 28, 173-174.

Marmur, J. (1961). A procedure for the isolation of deoxyribonucleic acid from microorganisms. J Mol Biol 3, 208-218.

Morita, R. Y. (1975). Psychrophilic bacteria. Bacteriol Rev 39, 144-167.

Oren, A. (2002). Diversity of halophilic microorganisms: environments, phylogeny, physiology, and applications. J Ind Microbiol Biotechnol 28, 56-63.

Reddy, G. S. N., Raghavan, P. U. M., Sarita, N. B., Prakash, J. S. S., Nagesh, N., Delille, D. \& Shivaji, S. (2003). Halomonas glaciei sp. nov. isolated from fast ice of Adelie Land, Antartica. Extremophiles 7, 55-61.

Risacher, F. (1992). Géochimie des lacs salés et croûtes de sel de l'Altiplano Bolivien. Sci Géol Bull 45, 135-214 (in French).
Saitou, N. \& Nei, M. (1987). The neighbor-joining method: a new method for reconstructing phylogenetic trees. Mol Biol Evol 4, 406-425.

Smibert, R. M. \& Krieg, N. R. (1994). Phenotypic characterization. In Methods for General and Molecular Bacteriology, pp. 607-655. Edited by P. Gerhardt, R. G. E. Murray, W. A. Wood \& N. R. Krieg. Washington, DC: American Society for Microbiology.

Tindall, B. J. (1994). Chemical analysis of Archaea and Bacteria: a critical evaluation of its use in taxonomy and identification. In Bacterial Diversity and Systematics (FEMS Symposium no. 75), pp. 243-258. Edited by F. G. Priest, A. Ramos-Cormenzana \& B. J. Tindall. New York: Plenum.

Ventosa, A., Quesada, E., Rodriguez-Valera, F., Ruiz-Berraquero, F. \& Ramos-Cormenzana, A. (1982). Numerical taxonomy of moderately halophilic Gram-negative rods. J Gen Microbiol 128, 1959-1968.

Ventosa, A., Nieto, J. J. \& Oren, A. (1998). Biology of moderately halophilic aerobic bacteria. Microbiol Mol Biol Rev 62, 504-544.

Vreeland, R. H., Litchfield, C. D., Martin, E. L. \& Elliot, E. (1980). Halomonas elongata, a new genus and species of extremely salttolerant bacteria. Int J Syst Bacteriol 30, 485-495.

Wayne, L. G., Brenner, D. J., Colwell, R. R. \& 9 other authors (1987). International Committee on Systematic Bacteriology. Report of the ad hoc committee on reconciliation of approaches to bacterial systematics. Int J Syst Bacteriol 37, 463-464.

Weisburg, W. G., Barns, S. M., Pelletier, D. A. \& Lane, D. J. (1991). $16 S$ ribosomal DNA amplification for phylogenetic study. J Bacteriol 173, 697-703. 